International Journal of Business Management and Economic Review

Vol. 5, No. 01; 2022

ISSN: 2581-4664

\title{
RESEARCH ON THE CUSTOMER LOYALTY STATUS AND PROMOTION STRATEGY OF THE JINGXI COMPANY
}

\author{
Li-Wei Lin ${ }^{1}$ and Shih-Yung Wei ${ }^{2 *}$ \\ ${ }^{1}$ School of Information, Zhejiang University of Finance and Economics Dongfang College, Zhejiang China \\ ${ }^{2}$ Business School of Yulin Normal University, Yulin, China \\ http://doi.org/10.35409/IJBMER.2022.3360
}

\begin{abstract}
With the development and popularization of the Internet, the competition of the major e-commerce platform is more and more fierce, customers become an important guarantee for the sustainable development of the enterprise, cultivate long-term loyal customers can bring long-term cumulative effect benefits to the enterprise, and customer loyalty and customer life cycle length, is the main factor to maintain the enterprise growth.This paper first introduces the background, status and development trend of e-commerce, analyzes the current development situation of Jingxi, discusses the influencing factors of customer loyalty and designs the questionnaire, analyzes the main influencing factors of Jingxi current customer loyalty and proposes the improvement strategy.
\end{abstract}

Keyword: Jingxi; customer loyalty; promotion strategy.

\section{INTRODUCTION}

\subsection{Research background}

In recent years, with the continuous development of the Internet, e-commerce has witnessed the rapid development of e-commerce. Compared with traditional shopping methods, mobile ecommerce is favored by consumers for its variety of goods, payment convenience and door-todoor delivery.

Since 2015, social e-commerce has begun to rise. As a new model of e-commerce, different from the traditional material-based e-commerce model, it adopts people-oriented sharing, interaction and communication through social media and other channels, so as to promote the sales and purchase of goods.

Social electricity by promoting the combination of social and e-commerce marketing model, with its precision marketing, high user viscosity, interactive, accurate user segmentation and huge business potential and low marketing and time cost advantages developed rapidly, attracted a large number of sinking market low income level, free time, sensitive to commodity prices.

Social e-commerce has attracted many enterprises to join in with its efficient customer acquisition ability and fission ability.In order to strive to win more markets, major platforms have launched social e-commerce platforms, among which three e-commerce giants: Jingdong launched Jingxi, Taobao launched Taobao special version to compete with Pinduoduo. 


\section{International Journal of Business Management and Economic Review}

Vol. 5, No. 01; 2022

ISSN: 2581-4664

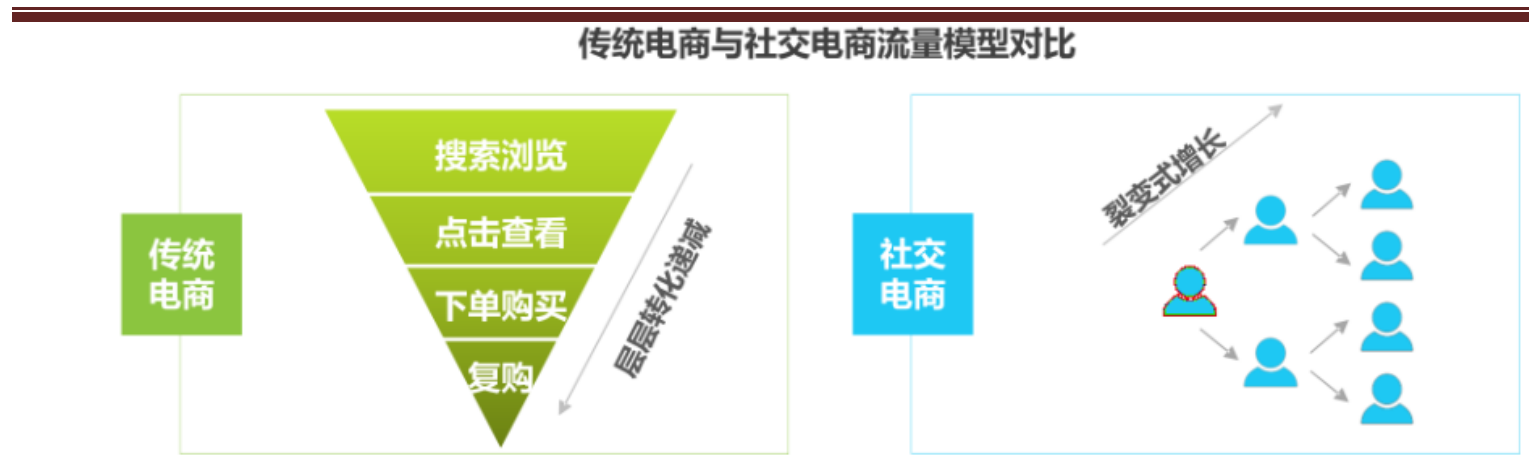

Figure 1-1 Comparison of traditional e-commerce and social e-commerce traffic model Figure $^{[1]}$

In terms of user scale, according to the 47th Statistical Report of China Internet Development

${ }^{[2]}$ released by China Internet Network Information Center, as of December 2020, the number of mobile Internet users in China has reached 989 million, an increase of 88.8.5 million compared with March 2020.The number of online shopping users in China reached 782 million, an increase of 72.15 million compared with March 2020, accounting for $79.1 \%$ of the overall Internet users.

From the market size, according to the forward-looking industry research institute released "China e-commerce industry market in 2020 market development situation analysis" [3] and "China e-commerce market competition and enterprise competition strategy analysis report" ${ }^{[4]}$ shows: in 2019 China's e-commerce transaction volume was 34.81 trillion yuan, up $10.05 \%$, among which 2019 China's online retail sales of 10.63 trillion yuan, year-on-year growth of $17.98 \%$.In 2019 , the transaction volume of social e-commerce exceeded 2 trillion yuan, accounting for $18.8 \%$ of the total scale of online retail, far higher than the overall growth rate of national online retail, and becoming an important support for the growth of online consumption. As a rapidly developing ecommerce model based on social networking, social e-commerce accounts for an increasing proportion of the online shopping market.

Under the fierce competition of major e-commerce platforms, the traffic of the first and second tier cities has gradually become saturated, and the traffic dividend has gradually disappeared. The "sinking market" has become the "last traffic dividend" of the Internet industry.According to the ${ }^{[5]}$ analysis of "2020 Sinking Market Map" by Mob Research Institute, the release of domestic urbanization dividend in 2020 has gradually entered a stable period, and the sinking market with 3, fourth and fifth tier cities and rural areas as the main body has become the incremental driving engine in the second half of the Internet.

Under the current fierce competition of many e-commerce platforms, how enterprises to seize the market and maintain their market position is very important.According to the research, compared with the impact of market share on the enterprise growth, customer loyalty has become the main factor to maintain the growth and competitive advantage of enterprises.Enterprises should not only continue to develop new users, open up new markets, improve the market share, but also strive to maintain the existing customers, cultivate long-term loyal customers, and stabilize the market share.

\subsection{Purpose and significance}

As the market competition becomes more fierce, the loyal customer is the strong capital of the enterprise, and the customer loyalty has become the determinant of the long-term profits.This article through the survey of Jingxi users, from the customer cognitive value, transfer cost, 
Vol. 5, No. 01; 2022

ISSN: 2581-4664

customer satisfaction, customer trust, hope to analyze the current customer loyalty and existing problems, and give some feasibility advice, so as to improve customer loyalty, stability and improve market share, form a strong competitive advantage.

\subsection{Research method}

\subsubsection{Literature analysis method}

Through China network, library books to search customer loyalty related literature, carefully reading analysis, learn and understand the customer loyalty research theory and the latest research results, enrich their cognition of the field, for the study of Beijing xi customer loyalty and influencing factors to lay the theoretical foundation.

\subsubsection{Questionnaire survey method}

According to the relevant theory of customer loyalty, the Jingxi customer loyalty questionnaire was designed for the influencing factors of customer loyalty. After completing the questionnaire writing, the questionnaire was distributed to different groups through the network, and the questionnaire data were collected in time.

\subsubsection{Data analysis method}

The collected questionnaire data were sorted out and analyzed, and charts were made for the corresponding problems of each influencing factor, accurately and intuitively analyze the current customer loyalty of Jingxi accurately and intuitively from the data, and put forward corresponding suggestions.

\subsubsection{Quantitative statistics}

The corresponding data were sorted out according to the questionnaire results, and the collected data for statistical analysis was conducted using SPSS22.0 statistical software. The main analysis methods used were: descriptive statistical analysis, reliability analysis, validity analysis, correlation analysis and linear regression analysis.Based on the basis of data analysis, the main influencing factors of current Jingxi customer loyalty were tested and explained.

\subsection{Study content of the paper}

This paper will combine the current development situation of Jingxi and the influencing factors of customer loyalty, study the questionnaire survey of customer loyalty to Jingxi, study the current customer loyalty situation of Jingxi, analyze the impact of these problems and propose solutions.

\section{LITERATURE REVIEW}

\subsection{The development trend of social e-commerce in China}

Social e-commerce is a new development mode of e-commerce in China. By realizing decentralization based on users, fission and communication are realized in the process of social networking, so as to reduce the customer acquisition cost of merchants and improve the efficiency of user transformation.In recent years, social e-commerce has grown rapidly in industry scale through its own advantages.It can be seen from Figure 2-1 that the scale of China's social ecommerce industry is gradually expanding, but the growth rate has slowed down for several years, which indirectly reminds that the dividend of social e-commerce enterprises is also gradually decreasing. It is particularly important how to quickly seize the market quickly at this time. 


\section{International Journal of Business Management and Economic Review}

Vol. 5, No. 01; 2022

ISSN: 2581-4664

\section{5-2021年中国社交电商行业规模及增速}

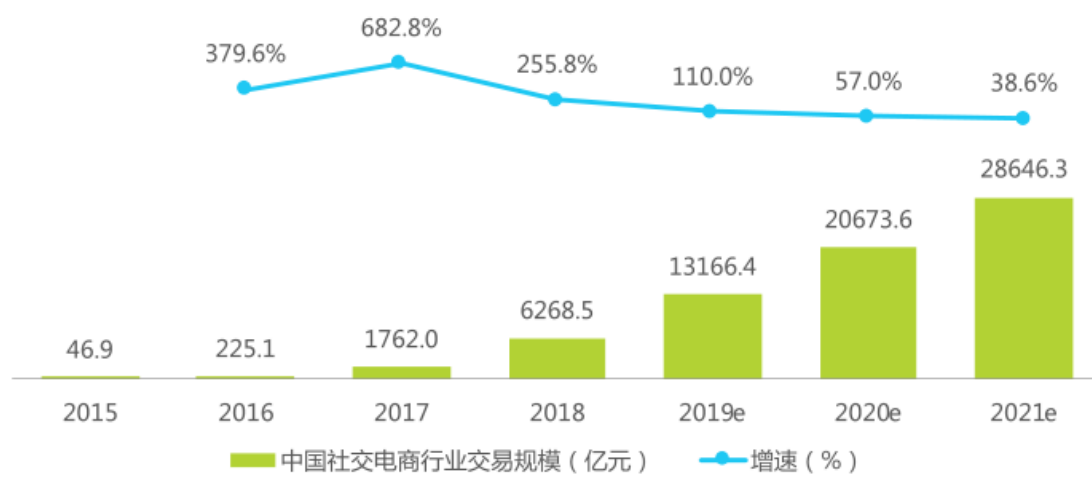

Figure 2-1 2015-2021 Scale and growth rate of China's social e-commerce industry in 2021 Figure ${ }^{[1]}$

\subsection{The development status of Jingxi}

Jingxi is a social e-commerce platform of JD. It is a global social e-commerce platform built by a comprehensively upgraded shopping business as the core, with WeChat as the main carrier, and based on six mobile channels, including wechat and Hand Q 200 million platforms. With the continuous development of social e-commerce, Jingxi focuses on the sinking market, connecting high-quality production capacity and consumer needs, and providing consumers with high-quality goods and services.

According to the 618 data of JD in 2019, the number of order users in the 3-6 cities increased by $106 \%$ year on year, and the users in the 3-6 market accounted for nearly $70 \%$. The number of new users of JD station through shopping increased by more than 3 times year-on-year.

According to the ${ }^{[6]}$ of QuestMobile Sinking Market Report in June 2019, the user scale of JD sinking market was about 130 million, and the overall sinking market scale of mobile shopping users in the same period was 520 million, accounting for $52.1 \%$, and the penetration rate was $25 \%$.

According to JD's 2011 Singles 11, nearly $40 \%$ of its new users come from Jingxi.More than $70 \%$ of Jingxi's users come from the sinking emerging markets on line 3-6, among which the new users from the sinking market account for $3 / 4$ of Jingxi's overall new users.

According to JD's 618 data in 2020, during the 618 period, young users in 3-6-tier cities grew the most rapidly, while high-tier cities are reflected in the substantial growth of middle-aged and elderly users.

According to the annual report released by JD Group in March 2021, the number of active purchasing users in the past 12 months has reached 471.9 million, with a net increase of nearly 110 million active users throughout the year, and more than $80 \%$ of the new active users came from the sinking market.According to the ${ }^{[7]}$ of the 2020 China Social E-commerce Consumer Shopping Behavior Research Report, the number of social e-commerce shopping users approached 7000 , and in 2020, more than 70 million social e-commerce employees appeared in 2020.

It can be seen from JD's data in recent years: Jingxi has released a surprising pull force in the sinking market, but according to the industry and user scale, Jingxi still has a lot of room to improvement in the sinking market. 
International Journal of Business Management and Economic Review

Vol. 5, No. 01; 2022

ISSN: 2581-4664

2.3 Concepts of customer loyalty

\subsubsection{CRM (customer relationship management)}

Customer Relationship Management (CRM) was proposed in 1999 by Gartner Group, the most authoritative IT research and customer consulting firm in China, but so far, there is no specific statement of what CRM is.

For the view of scholars in various fields, I agree with Harvard University Joan Settlement (Jon Anton) said "CRM is the seamless access of internal and external customers to enterprise information, through the integration of enterprise telephone system, websites and email contact points, is the customer can achieve important product purchase through independent service, guide rational incremental sales and cross-sales, and finally improve customer loyalty, customer value and customer profit margin".

CRM takes customers as the most important part of enterprise assets, customer-centered to help enterprises to build good relations with customers, in the development of customer satisfaction and cultivate customer loyalty development, while achieving the strategic goal of maximizing enterprise profits and long-term development.

In the era of many e-commerce platforms, only by managing and operating good customer relations can we achieve the long-term development of the platform.

\subsubsection{Definition of customer loyalty}

Customer loyalty is when the customer has a good impression and trust in a particular product or service and tends to repurchase the original product at the next purchase.Customer loyalty is an important determinant of enterprise competitiveness, and the establishment of customer loyalty has become the cornerstone of enterprise growth and the foundation of survival. ${ }^{[8]}$

Customer loyalty includes emotional loyalty and behavioral loyalty ${ }^{[9]}$ emotional loyalty is the customer's attitude towards the enterprise and its products or services, including the initiative to recommend enterprise products and services to people around, or the customer has the intention to buy for the enterprise or brand, just love the enterprise or brand, but did not buy; and behavior loyalty is the repeated purchase behavior.The most fundamental difference between the two is that emotional loyalty does not produce direct value, and behavioral loyalty can directly produce value, making customers change from "thinking" to "do", thus greatly improving the transaction quality of customers and enterprises.

\subsubsection{The benefits that customer loyalty brings to businesses}

Customer loyalty has a greater impact on corporate profitability and growth than market share.Customer loyalty is the main factor in maintaining the growth and plays a key role in the profitability.

(1) increase income.

The financial benefits of loyal customers to enterprises are reflected in repeated purchases, price premium and wallet share.Loyal customers tend to buy corporate products repeatedly.Unlike new customers, they are less price sensitive because they trust corporate products. So when buying such products, they prioritize and buy loyal business products, namely increasing the share of their wallets.

Customers who repeatedly purchase tend to form a certain relationship with the enterprise, which is conducive to enterprises to customize long-term planning, so that enterprises are able to design and establish low-cost working ways that meet customer needs. ${ }^{[10]}$

(2) cut the cost. 


\section{International Journal of Business Management and Economic Review}

Vol. 5, No. 01; 2022

ISSN: 2581-4664

Loyalty customers can allow enterprises to save marketing costs, service costs, error costs, and new customer acquisition costs. The cost of developing a new customer is about 5-10 times the cost of maintaining an old customer.In the sales process, different from the distrust of new customers, old customers save the cost of enterprise advertising and promotion. In the After-sales process, because old customers have used the product, they are familiar with the relevant operation, and the after-sales cost is low.

(3) Word-of-mouth effect.

One of the golden rules of marketing costs: developing 10 new customers is better to maintain an old customer.Because 1 satisfied old customer $=8$ potential new customers, and 1 dissatisfied old customer $=25$ fewer potential new customers.

Customer satisfaction will enhance the image of the enterprise in the eyes of consumers. Loyalty customers are like free marketers of the enterprise. When they repeatedly buy the products or services of the enterprise, they will make positive oral publicity to the enterprise products or services, so as to drive the consumption of the groups around them.Different from enterprise publicity, customers believe more in what the customer said, so the effect of customer publicity is better than that of enterprise publicity.

Compared with mass media, word-of-mouth communication not only has a strong credibility, but also has vitality, easy to remember, so it has a great impact on consumers, and word-of-mouth marketing also uses the nature of human information communication, making the communication cost almost zero.

The power of word of mouth, often lead to double chain reactions and profits. Therefore, loyal customers are the priceless assets of enterprises, we should pay attention to the service and maintenance of old customers, and improve the introduction rate of old customers.

(4) Carry out key work

When the customer is a loyal customer, enterprise customer group stable, the enterprise has time to develop new customers, create new value appreciation, focus on improving the quality of products and improve the existing service system, can promote the enterprise gradually on the road of stable development, and growing in the competition. ${ }^{[1]}$

(5) Helps the company to launch other new products

Loyal customers are more receptive to new corporate products.There is also innate trust in new products, which can be constantly repeatedly purchased, so that the profits of enterprises can be improved.At the same time, the emergence of new products will expand the scope of customers, and enterprises can gain greater customer loyalty to a certain extent.

\subsubsection{Factors affecting customer loyalty}

Domestic scholars Chen Mingliang will be four measures of customer loyalty (i. e., repeated purchase intention, cross purchase intention, customer recommendation intention, price tolerance) and the four determinants of customer loyalty, and the mutual relationship between each other, put forward the customer loyalty theory model ${ }^{[12]}$, as shown in figure 2-2.

(1) Customer cognitive value

Customer cognitive value refers to the customer evaluation of the satisfaction with enterprise service and the subjective judgment of the value provided by suppliers.

The fundamental motivation for customer loyalty is customer value.Customers in the process of shopping hope to get the maximum value at the minimum cost, so as to get the maximum satisfaction, if the customer in the selected service or product obtained excellent quality, 
Vol. 5, No. 01; 2022

ISSN: 2581-4664

preferential price, quality service is beyond the customer expectations, will leave a very deep impression on the customer, thus produce good results.

(2) cost of transfer

Transfer cost refers to the subjective perception of the relevant costs involved in ending the relationship with the current supplier and establishing a new alternative relationship.Customers usually consider the customer in terms of value and cost in the purchase process. For old customers, if they change the seller or brand is replaced, it will be affected by delayed interests and transfer costs.And trying new products to bear certain risks, and in the access may not be comparable to the original brand or enterprise.

Businesses generally segment customers based on their own value and profit margin, giving more attention to high-value customers, ensuring that they can get some special services and treatment, thus cultivating them into loyal customers of the enterprise.

The more customers buy, the higher the level, and the higher the level can enjoy special activities.For example, if a customer uses a shopping software for a long time, he will buy the product with the corresponding points. The points accumulated to a certain number of points can be deducted from the purchase amount at the next purchase, but this can only be deducted when buying on the platform.Loyalty customers will get more discounts on the platform than on other platforms.

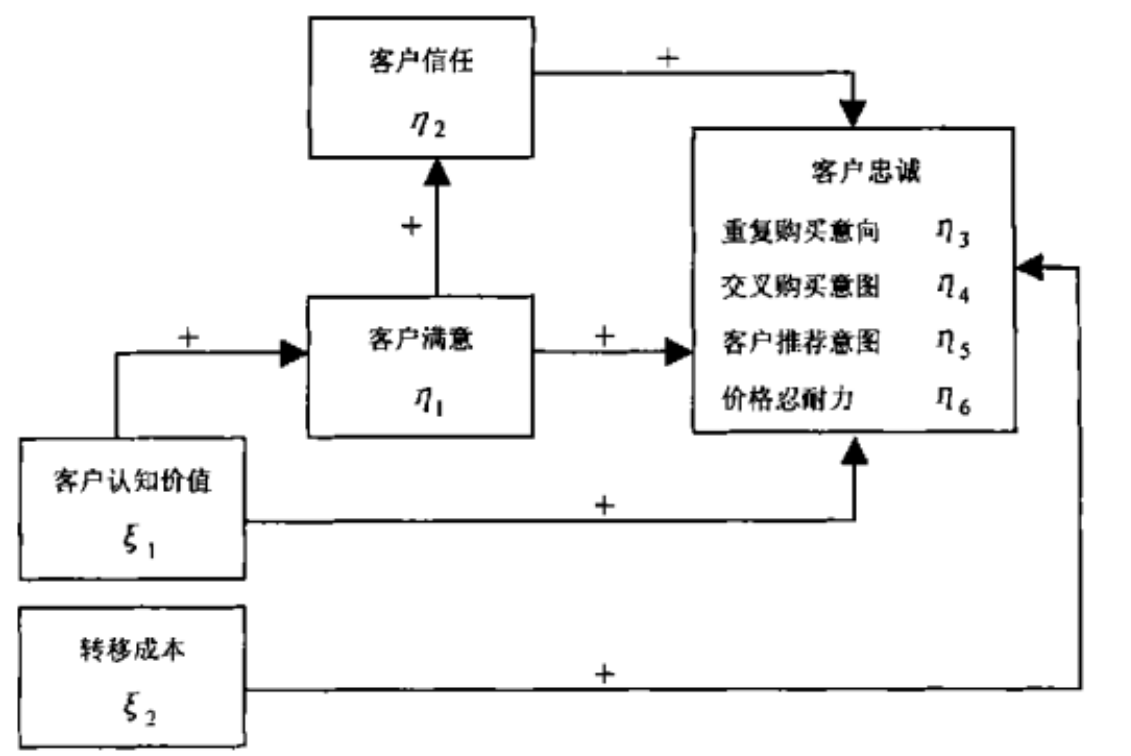

Figure 2-2 Customer Loyalty Theory Model ${ }^{[12]}$

\section{(3) Customer satisfaction}

Customer satisfaction is the feeling state formed by the customer's perception of the product when compared with the expected value. It emphasizes the customer satisfaction with the product or service of the enterprise, and the customer will only be satisfied when the product meets the 
International Journal of Business Management and Economic Review

Vol. 5, No. 01; 2022

ISSN: 2581-4664

customer expectations.

Customer satisfaction is closely related to customer loyalty, and customer satisfaction is positively acting on customer loyalty. On the one hand, customer satisfaction is an effective way to achieve customer loyalty. Customers will only be satisfied with the products or services provided by the enterprise, they will have the desire to continue to repeat the purchase.But even if the customer is very satisfied, there may not be a desire to repeat the purchases.On the other hand, customer satisfaction is on customer loyalty as the fulcrum.Customer satisfaction If it cannot make the customer loyal, it loses its meaning.

Therefore, customer loyalty is based on a certain satisfaction, at this level, customer loyalty is low; customer loyalty is not affected; but if customer satisfaction is very high, loyalty will increase significantly.

(4) Customer trust

Customer trust refers to the customer's willingness to rely on the trusted trading partner, which will produce affirmation, recognition and trust.Trust consists of two dimensions: credibility and friendliness.

Credibility is the degree of confidence in the trading partner's ability to complete the work effectively and reliably;

Friendliness is the degree of belief in the altruistic (opposing) intent and motivation of the trading partner when new or not taken into account in the commitment.

Customer trust affects customer relationships through three mechanisms, which can then affect the development of customer loyalty: reducing customer concerns about the risks caused by supplier speculation, increasing customer confidence in long-term returns, and reducing transaction costs.

Customer trust is the result of constantly strengthening customer satisfaction, is the basis of customer loyalty, to successfully establish a high level of long-term customer loyalty must focus on customer trust.

\section{JINGXI CUSTOMER LOYALTY EMPIRICAL ANALYSIS}

3.1 Questionnaire design and determination of the scales

Questionnaire design is divided into two parts, the first part is the basic situation of users, a total of 5 questions, the second part is to investigate customer loyalty to Beijing, using ert (Likert) five scale, for each item set "very disagree", "disagree" agree "agree", "basic" agree "," agree "five options, respectively divided into" 1 "," 2 "," 3 "," 4 "," 5 ", a total of 25 questions.(See Table 3-1 for specific topic distribution)

Table 3-1 Distribution of questionnaire questions set

\begin{tabular}{|c|c|c|}
\hline PART one & fundamental state & T1-T5 \\
\hline \multirow{5}{*}{ PART tow } & $\begin{array}{l}\text { Cognitive value of } \\
\text { customers }\end{array}$ & T1-T5 \\
\hline & transfer cost & T6-T10 \\
\hline & Customer satisfaction & $\mathrm{T} 11-\mathrm{T} 15$ \\
\hline & Customer trust & T16-T20 \\
\hline & loyalty & $\mathrm{T} 21-\mathrm{T} 25$ \\
\hline
\end{tabular}

\subsection{Statistical analysis of the results of the questionnaire survey}


The paper questionnaire by random sampling survey, questionnaire mainly through network platform channels, mainly survey the loyalty of Beijing xi platform, to analyze its present customer loyalty and commission advice, a total of 176 questionnaires, delete 7 , effective recovery questionnaire 169 , effective recovery rate is $96 \%$.

\subsubsection{Descriptive statistical analysis of the basic information}

Table 32 Frequency analysis of the demographic variables

\begin{tabular}{|c|c|c|c|c|c|}
\hline Variable & Option & & percentage & Mean & SD \\
\hline \multirow{2}{*}{ Sex } & Man & 65 & $38.50 \%$ & \multirow{2}{*}{1.62} & \multirow{2}{*}{0.49} \\
\hline & Woman & 104 & $61.50 \%$ & & \\
\hline \multirow{5}{*}{ Age } & Under the age of 18 & 1 & $0.60 \%$ & \multirow{5}{*}{2.98} & \multirow{5}{*}{0.72} \\
\hline & $18-25$ year & 37 & $21.90 \%$ & & \\
\hline & $26-35$ year & 101 & $59.80 \%$ & & \\
\hline & $36-45$ year & 25 & $14.80 \%$ & & \\
\hline & Over 45 years of age & 5 & $3.00 \%$ & & \\
\hline \multirow{4}{*}{ Education } & High school or below & 9 & $5.30 \%$ & \multirow{4}{*}{2.60} & \multirow{4}{*}{0.65} \\
\hline & Junior college & 56 & $33.10 \%$ & & \\
\hline & Undergraduate course & 98 & $58.00 \%$ & & \\
\hline & Master's degree or above & & $3.60 \%$ & & \\
\hline \multirow{5}{*}{ Monthly income } & Below RMB 1,000 yuan & 17 & $10.10 \%$ & \multirow{5}{*}{2.67} & \multirow{5}{*}{0.92} \\
\hline & RMB $1,000-1,500$ yuan & 51 & $30.20 \%$ & & \\
\hline & RMB $1,501-3,500$ yuan & 79 & $46.70 \%$ & & \\
\hline & RMB 3,501-5,000 yuan & 15 & $8.90 \%$ & & \\
\hline & Above RMB 5,000 yuan & & $4.10 \%$ & & \\
\hline
\end{tabular}

Numerical numerical features of the descriptive statistical analysis can reflect the distribution of the subjects investigated. Where the mean represents a concentrated trend, the standard deviation represents the fluctuating situation.

According to the results of the frequency analysis of the various variables in Table 3-2, the distribution basically meets the requirements of the sampling survey.

According to the survey results, the proportion of men is $38.5 \%$ and $61.5 \%$, which shows that women are more willing to follow than men in the context of online shopping;

Among the respondents, the customer group was aged 26-35, indicating that young and middle-aged users were the main force of Jingxi users. College and undergraduate students accounted for about $90 \%$ of the total sample; monthly income was 1000-1500 and 1500-3500.

\subsubsection{Reliability analysis}

Reliability analysis is reliability analysis, mainly to test whether the scale has stability and consistency in the measurement-related variables.Clone Bach coefficient (Cronbach's alpha) was used to test the reliability of the questionnaire.The larger the value means the higher the questionnaire reliability, the Cronbach's alpha value below 0.6 should consider recompiling the questionnaire, which is acceptable between 0.6 and 0.7 , better between 0.7 and 0.8 , and above 0.8 indicates. Very good.

(1) Customer cognitive value 


\section{Table 3-3 Analysis of customer cognitive value reliability}

\begin{tabular}{|c|c|c|c|c|c|c|}
\hline Option & $\begin{array}{l}\text { Scaling } \\
\text { average } \\
\text { after } \\
\text { deleting } \\
\text { the item }\end{array}$ & $\begin{array}{l}\text { The } \\
\text { scaling } \\
\text { variance } \\
\text { after } \\
\text { deleting } \\
\text { the item }\end{array}$ & $\begin{array}{l}\text { Project } \\
\text { correlation } \\
\text { with total } \\
\text { score after } \\
\text { correction }\end{array}$ & $\begin{array}{l}\text { Square } \\
\text { multipl } \\
\text { e } \\
\text { correla } \\
\text { tions }\end{array}$ & $\begin{array}{l}\text { Clone } \\
\text { Bach } \\
\text { coefficient } \\
\text { after item } \\
\text { deletion }\end{array}$ & $\begin{array}{l}\text { Stan } \\
\text { dard } \\
\text { ized } \\
\text { Alph } \\
\text { a }\end{array}$ \\
\hline $\begin{array}{l}\text { (1) Buying goods in } \\
\text { Jingxi is consistent with } \\
\text { the product main picture } \\
\text { after receiving the goods }\end{array}$ & 15.02 & 6.047 & 0.618 & 0.41 & 0.786 & \\
\hline $\begin{array}{l}\text { (2) After entering the } \\
\text { Jingxi page, it is very } \\
\text { convenient to screen the } \\
\text { goods you want }\end{array}$ & 14.93 & 5.716 & 0.712 & 0.509 & 0.759 & 0.82 \\
\hline $\begin{array}{l}\text { (3) The design of the } \\
\text { Jingxi page is very } \\
\text { comfortable }\end{array}$ & 15.22 & 5.553 & 0.607 & 0.389 & 0.791 & 0. \\
\hline $\begin{array}{l}\text { (4) The pricing is } \\
\text { reasonable in Jingxi }\end{array}$ & 14.97 & 6.1 & 0.616 & 0.386 & 0.787 & \\
\hline $\begin{array}{l}\text { (5) Jingxi offers a } \\
\text { complete range of } \\
\text { commodities }\end{array}$ & 14.93 & 6.031 & 0.54 & 0.326 & 0.809 & \\
\hline
\end{tabular}

According to the results of the reliability analysis in Table 3-3, the overall standardized reliability coefficient in the customer cognitive value is 0.825 , and according to the reliability coefficient after the item deletion, it can be seen as less than the overall 0.825 , and the reliability is relatively good.Therefore, the topic of customer cognitive value content dimension does not need to be adjusted.

(2) Cost of transfer

Table 3-4 Transfer cost reliability analysis

\begin{tabular}{|c|c|c|c|c|c|c|}
\hline Option & $\begin{array}{l}\text { Scaling } \\
\text { average } \\
\text { after } \\
\text { deleting } \\
\text { the item }\end{array}$ & $\begin{array}{l}\text { The } \\
\text { scaling } \\
\text { variance } \\
\text { after } \\
\text { deleting } \\
\text { the item }\end{array}$ & $\begin{array}{l}\text { Project } \\
\text { correlation } \\
\text { with total } \\
\text { score after } \\
\text { correction }\end{array}$ & $\begin{array}{l}\text { Squar } \\
\mathrm{e} \\
\text { multip } \\
\text { le } \\
\text { correl } \\
\text { ations }\end{array}$ & $\begin{array}{l}\text { Clone } \\
\text { Bach } \\
\text { coefficie } \\
\text { nt after } \\
\text { item } \\
\text { deletion }\end{array}$ & $\begin{array}{l}\text { Stan } \\
\text { dard } \\
\text { ized } \\
\text { Alp } \\
\text { ha }\end{array}$ \\
\hline $\begin{array}{l}\text { (6) Compared with other } \\
\text { websites, the invited new } \\
\text { benefits accumulated on } \\
\text { Jingxi can enjoy greater } \\
\text { discounts }\end{array}$ & 13.54 & 7.464 & 0.77 & 0.66 & 0.923 & $\begin{array}{l}0.93 \\
5\end{array}$ \\
\hline
\end{tabular}


International Journal of Business Management and Economic Review

Vol. 5, No. 01; 2022

ISSN: 2581-4664

(7) Compared with other websites, I are more satisfied with the shopping red envelope activity launched by $\begin{array}{lllll}13.59 & 7.006 & 0.868 & 0.763 & 0.902\end{array}$ Jingxi

(8) Compared with other websites, being familiar with Jingxi shopping platforms needs a lot of energy, and it is
13.64
7.623
0.772
0.604
0.921

easy to accept

(9) Compared to other websites, it is easy to search for the same products on $\begin{array}{lllll}13.46 & 8.381 & 0.828 & 0.8 & 0.914\end{array}$ other platforms on Jingxi (10) If you use other websites for shopping, you will lose the good products and $\begin{array}{lllll}13.49 & 7.894 & 0.881 & 0.836 & 0.902\end{array}$ services provided by Jingxi

According to the results of the reliability analysis in Table 34, the overall standardized reliability coefficient on the customer transfer cost is 0.935 , and according to the reliability coefficient after the item deletion, it can be seen as less than the overall 0.935 , and the reliability is relatively good.Therefore, the topic of the transfer cost content dimension does not need to be adjusted.

(3) Customer satisfaction

Table 3-5 Analysis of customer satisfaction

\begin{tabular}{|c|c|c|c|c|c|c|}
\hline Option & $\begin{array}{l}\text { Scaling } \\
\text { average } \\
\text { after } \\
\text { deleting } \\
\text { the item }\end{array}$ & $\begin{array}{l}\text { The scaling } \\
\text { variance } \\
\text { after } \\
\text { deleting } \\
\text { the item }\end{array}$ & $\begin{array}{l}\text { Project } \\
\text { correlation } \\
\text { with total } \\
\text { score after } \\
\text { correction }\end{array}$ & $\begin{array}{l}\text { Square } \\
\text { multipl } \\
\mathrm{e} \\
\text { correla } \\
\text { tions } \\
\end{array}$ & $\begin{array}{l}\text { Clone } \\
\text { Bach } \\
\text { coefficient } \\
\text { after item } \\
\text { deletion }\end{array}$ & $\begin{array}{l}\text { Normaliz } \\
\text { ed post- } \\
\text { invasive } \\
\text { condition } \\
\mathrm{s}\end{array}$ \\
\hline $\begin{array}{l}\text { (11) Shopping on } \\
\text { the Jingxi } \\
\text { platform is very } \\
\text { simple and } \\
\text { convenient }\end{array}$ & 14.08 & 7.529 & 0.746 & 0.564 & 0.901 & \\
\hline $\begin{array}{l}\text { (12) Jingxi } \\
\text { platform has a } \\
\text { fast transaction } \\
\text { processing speed }\end{array}$ & 14.41 & 6.291 & 0.885 & 0.848 & 0.867 & 0.914 \\
\hline $\begin{array}{l}\text { (13) Jingxi } \\
\text { commodities are } \\
\text { very cost- } \\
\text { effective }\end{array}$ & 14.43 & 6.937 & 0.693 & 0.504 & 0.909 & \\
\hline
\end{tabular}


International Journal of Business Management and Economic Review

Vol. 5, No. 01; 2022

ISSN: 2581-4664

\begin{tabular}{|c|c|c|c|c|c|}
\hline $\begin{array}{lr}(14) & \text { Jingxi's } \\
\text { after-sales service } \\
\text { is } \\
\text { professional }\end{array}$ & 14.39 & 6.335 & 0.786 & 0.713 & 0.891 \\
\hline $\begin{array}{l}\text { (15) Jingxi after- } \\
\text { sales service } \\
\text { response is very } \\
\text { timely }\end{array}$ & 14.36 & 6.647 & 0.797 & 0.735 & 0.887 \\
\hline
\end{tabular}

According to the results of the reliability analysis in Table 3-5, the overall standardized reliability coefficient on customer satisfaction is 0.914 , and according to the reliability coefficient after item deletion, it can be seen as less than the overall 0.914 , and the reliability is relatively good.Therefore, the topic of the customer satisfaction content dimension does not need to be adjusted.

(4) Customer trust

Table 3-6 Analysis of Customer trust

According to the results of the reliability analysis in Table 3-6, the overall standardized

\begin{tabular}{|c|c|c|c|c|c|c|}
\hline Option & $\begin{array}{l}\text { Scaling } \\
\text { average } \\
\text { after } \\
\text { deleting } \\
\text { the item }\end{array}$ & $\begin{array}{l}\text { The } \\
\text { scaling } \\
\text { variance } \\
\text { after } \\
\text { deleting } \\
\text { the item }\end{array}$ & $\begin{array}{l}\text { Project } \\
\text { correlatio } \\
\mathrm{n} \quad \text { with } \\
\text { total score } \\
\text { after } \\
\text { correction }\end{array}$ & $\begin{array}{l}\text { Squar } \\
\mathrm{e} \\
\text { multi } \\
\text { ple } \\
\text { correl } \\
\text { ations }\end{array}$ & $\begin{array}{l}\text { Clone } \\
\text { Bach } \\
\text { coefficie } \\
\text { nt after } \\
\text { item } \\
\text { deletion }\end{array}$ & $\begin{array}{l}\text { Sta } \\
\text { nda } \\
\text { rdiz } \\
\text { ed } \\
\text { Alp } \\
\text { ha }\end{array}$ \\
\hline $\begin{array}{l}\text { (16) Shopping on the Jingxi } \\
\text { platform has high security }\end{array}$ & 14.14 & 5.884 & 0.709 & 0.53 & 0.845 & \multirow{5}{*}{$\begin{array}{l}0.8 \\
77\end{array}$} \\
\hline $\begin{array}{l}\text { (17) When shopping on the Jingxi } \\
\text { platform, the price is rarely judged } \\
\text { through other shopping APP } \\
\text { comparison }\end{array}$ & 14.56 & 6.081 & 0.588 & 0.377 & 0.875 & \\
\hline $\begin{array}{l}\text { (18) All the goods purchased on } \\
\text { the Jingxi platform can be } \\
\text { delivered as scheduled and intact }\end{array}$ & 14.22 & 6.021 & 0.794 & 0.707 & 0.828 & \\
\hline $\begin{array}{l}\text { (19) When the goods are damaged } \\
\text { in the process of logistics, or they } \\
\text { have problems in the process of } \\
\text { use, Jingxi customer service can } \\
\text { solve the problem very well }\end{array}$ & 14.3 & 5.805 & 0.722 & 0.644 & 0.841 & \\
\hline $\begin{array}{l}\text { (20) You believe that Jingxi will } \\
\text { continue to improve its service } \\
\text { ability and level in the future }\end{array}$ & 13.99 & 5.696 & 0.717 & 0.543 & 0.843 & \\
\hline
\end{tabular}

reliability coefficient on customer trust is 0.877 , and according to the reliability coefficient after item deletion, it can be seen as less than the overall 0.877 , and the reliability is relatively good.Therefore, the topic of the customer trust content dimension does not need to be adjusted. 
International Journal of Business Management and Economic Review

Vol. 5, No. 01; 2022

ISSN: 2581-4664

(5) Customer loyalty

Table 3-7 Analysis of Customer Loyalty

\begin{tabular}{|c|c|c|c|c|c|c|}
\hline Option & $\begin{array}{l}\text { Scaling } \\
\text { average } \\
\text { after } \\
\text { deleting } \\
\text { the item }\end{array}$ & $\begin{array}{l}\text { The } \\
\text { scaling } \\
\text { variance } \\
\text { after } \\
\text { deleting } \\
\text { the item }\end{array}$ & $\begin{array}{l}\text { Project } \\
\text { correlatio } \\
\mathrm{n} \quad \text { with } \\
\text { total } \\
\text { score } \\
\text { after } \\
\text { correctio } \\
\mathrm{n}\end{array}$ & $\begin{array}{l}\text { Square } \\
\text { multipl } \\
\mathrm{e} \\
\text { correlat } \\
\text { ions }\end{array}$ & $\begin{array}{l}\text { Clone } \\
\text { Bach } \\
\text { coeffici } \\
\text { ent after } \\
\text { item } \\
\text { deletion }\end{array}$ & $\begin{array}{l}\text { Standa } \\
\text { rdized } \\
\text { Alpha }\end{array}$ \\
\hline $\begin{array}{l}\text { (21) When you want to buy } \\
\text { things, you will choose the } \\
\text { Jingxi platform for buy }\end{array}$ & 13.1 & 4.591 & 0.688 & 0.501 & 0.849 & \multirow{5}{*}{0.875} \\
\hline $\begin{array}{l}(22) \text { For you, Jingxi } \\
\text { platform is the best } \\
\text { shopping website }\end{array}$ & 13.15 & 4.913 & 0.656 & 0.443 & 0.855 & \\
\hline $\begin{array}{l}\text { (23) Even if other websites } \\
\text { offer the same or lower } \\
\text { price, you will not easily } \\
\text { change the website }\end{array}$ & 13.61 & 4.942 & 0.763 & 0.668 & 0.833 & \\
\hline $\begin{array}{l}\text { (24) Even if the price of } \\
\text { Jingxi provides products or } \\
\text { services increases, you will } \\
\text { still choose to buy it }\end{array}$ & 13.43 & 4.71 & 0.701 & 0.626 & 0.844 & \\
\hline $\begin{array}{l}\text { (25) You believe that Jingxi } \\
\text { can meet your shopping } \\
\text { needs }\end{array}$ & 12.75 & 4.831 & 0.703 & 0.508 & 0.844 & \\
\hline
\end{tabular}

According to the results of the reliability analysis in Table 3-7, the overall standardized reliability coefficient in customer loyalty is 0.875 , according to the reliability coefficient after item deletion, it can be less than 0.875 , the reliability is relatively good.Therefore, the topic of the customer trust content dimension does not need to be adjusted.

(6) Overall reliability coefficient

Table 3-8 Reliability statistics

\begin{tabular}{|llll|}
\hline $\begin{array}{l}\text { Clone } \\
\text { coefficients }\end{array}$ & Bach & $\begin{array}{l}\text { Clonal Bach coefficients based on the standardized } \\
\text { project }\end{array}$ & $\begin{array}{l}\text { number } \\
\text { terms }\end{array}$
\end{tabular}

According to the overall reliability coefficient of Table 3-8, the standardized clonal Bach coefficient position is 0.961 , indicating that the overall confidence of the questionnaire is very high.

\subsection{3 analysis of validity}

Validity analysis refers to whether the measurement scale can correctly measure the degree of characteristics predicted by the researcher. ${ }^{[13]}$ 
International Journal of Business Management and Economic Review

Vol. 5, No. 01; 2022

ISSN: 2581-4664

\section{Table 3-9KMO and Barlitt tests}

\begin{tabular}{|lll|}
\hline \multicolumn{2}{l}{ Number of KMO sampling suitability quantities } & 0.92 \\
\hline & The card side that was last read & 3535.363 \\
Bartlett's spherical degree test & Free degree & 300 \\
& Significance & 0 \\
\hline
\end{tabular}

According to the results of the exploratory analysis in Table 3-9, the coefficient result of the KMO test is 0.92 , and the coefficient values of the KMO test range from $0-1$. The closer the 1 indicates that the better the validity of the questionnaire.

It can also be seen that according to the significance of the spherical test, the significance of this test is infinitely close to 0 , so the questionnaire has good validity.

\subsection{4 relevance analysis}

Correlation analysis is a statistical method to study the correlation between phenomena, and to explore the direction and degree of correlation, and to study the correlation of random variables.

Table 3-10 Correlation analysis across the various dimensions

\begin{tabular}{|c|c|c|c|c|c|c|}
\hline variable & relativity & $\begin{array}{l}\text { Cognitive value } \\
\text { of customers }\end{array}$ & $\begin{array}{l}\text { transfe } \\
\mathrm{r} \text { cost }\end{array}$ & $\begin{array}{l}\text { Customer } \\
\text { satisfaction }\end{array}$ & $\begin{array}{l}\text { Custome } \\
\mathrm{r} \text { trust }\end{array}$ & $\begin{array}{l}\text { loya } \\
\text { lty }\end{array}$ \\
\hline $\begin{array}{l}\text { Cognitive value } \\
\text { of customers }\end{array}$ & $\begin{array}{l}\text { Pearson } \\
\text { correlation }\end{array}$ & 1 & & & & \\
\hline transfer cost & $\begin{array}{l}\text { Pearson } \\
\text { correlation }\end{array}$ & $.589 * *$ & 1 & & & \\
\hline $\begin{array}{l}\text { Customer } \\
\text { satisfaction }\end{array}$ & $\begin{array}{l}\text { Pearson } \\
\text { correlation }\end{array}$ & $.733^{* *}$ & $.571 * *$ & 1 & & \\
\hline $\begin{array}{l}\text { Customer } \\
\text { satisfaction }\end{array}$ & $\begin{array}{l}\text { Pearson } \\
\text { correlation }\end{array}$ & $.694 * *$ & $.545^{* *}$ & $.763^{* *}$ & 1 & \\
\hline loyalty & $\begin{array}{l}\text { Pearson } \\
\text { correlation }\end{array}$ & $.743 * *$ & $.620 * *$ & $.803 * *$ & $.809 * *$ & 1 \\
\hline
\end{tabular}

Results of correlation analysis: * indicates significant correlation above $95 \%{ }^{*} *$ Represents a significant correlation above $99 \%$, and $* * *$ indicates a significance-level correlation above 99.9\%.

According to the correlation results of the analysis in Table 3-10, each variable had significant correlations at the $99 \%$ significance level, and the correlation coefficients were greater than 0 , so all were positive correlations.

For example, the correlation coefficient between customer cognitive value and transfer cost is 0.589 , a positive correlation. And so on can explain the correlations between all the other variables.

\subsection{5 regression analysis}

Regression analysis is mainly to study how much one variable or multiple variable changes changes on the other variable. The magnitude of the influence of the independent variables on the dependent variables can be seen by the regression coefficients.

This paper constructs multiple linear regression models to test the significance of analyzing 
International Journal of Business Management and Economic Review

Vol. 5, No. 01; 2022

ISSN: 2581-4664

independent variables on the dependent variables, using loyalty as the dependent variable, customer cognitive value, transfer cost, customer satisfaction and customer trust as the dependent variables.

Table 3-11 Regression analysis of customer loyalty factors

\begin{tabular}{|c|c|c|c|c|c|c|c|c|}
\hline \multirow{2}{*}{ variable } & \multirow{2}{*}{$\begin{array}{l}\text { Non- } \\
\text { standardized } \\
\text { coefficients } \\
\text { B }\end{array}$} & \multirow{2}{*}{$\begin{array}{l}\text { Standa } \\
\text { rd error }\end{array}$} & $\begin{array}{l}\text { Standard } \\
\text { coefficien } \\
t\end{array}$ & \multirow{2}{*}{$\mathrm{t}$} & \multirow{2}{*}{$\begin{array}{l}\text { Signif } \\
\text { icance }\end{array}$} & \multicolumn{2}{|c|}{$\begin{array}{l}\text { Collinear } \\
\text { statistics }\end{array}$} & \multirow{2}{*}{$\begin{array}{l}\text { Adjusted } \\
\text { R square }\end{array}$} \\
\hline & & & Beta & & & $\begin{array}{l}\text { Tole } \\
\text { rate }\end{array}$ & VIF & \\
\hline (constant) & 1.025 & 0.694 & & $\begin{array}{l}1 . \\
47 \\
7\end{array}$ & 0.142 & & & \\
\hline $\begin{array}{l}\text { Cognitive } \\
\text { value } \\
\text { customers }\end{array}$ & 0.157 & 0.055 & 0.173 & $\begin{array}{l}2 . \\
87 \\
7\end{array}$ & 0.005 & $\begin{array}{l}0.39 \\
1\end{array}$ & $\begin{array}{l}2.5 \\
57\end{array}$ & \\
\hline Transfer cost & 0.105 & 0.038 & 0.134 & $\begin{array}{l}2 . \\
76 \\
4\end{array}$ & 0.006 & $\begin{array}{l}0.60 \\
2\end{array}$ & $\begin{array}{l}1.6 \\
61\end{array}$ & 0.762 \\
\hline $\begin{array}{l}\text { Customer } \\
\text { satisfaction }\end{array}$ & 0.26 & 0.055 & 0.309 & $\begin{array}{l}4 . \\
71 \\
7\end{array}$ & 0 & 0.33 & $\begin{array}{l}3.0 \\
34\end{array}$ & \\
\hline Customer trust & 0.342 & 0.056 & 0.379 & $\begin{array}{l}6 . \\
15\end{array}$ & 0 & $\begin{array}{l}0.37 \\
3\end{array}$ & $\begin{array}{l}2.6 \\
83\end{array}$ & \\
\hline
\end{tabular}

As can be seen from Table 3-11, the adjusted $\mathrm{R}$ square is 0.762 , the closer the $\mathrm{R}$ square between $0-1$, the better the model fit, there is a clear linear relationship between loyalty and customer cognitive value, transfer cost, customer satisfaction and customer trust, so this questionnaire is meaningful.

At the same time, the regression constant is 1.025 , customer cognitive value, transfer cost, customer satisfaction, customer trust to loyalty is $0.173,0.13,0.134,0.309$ and 0.379 , and the significance level is below 0.05 indicates a significant impact relationship, which shows that customer cognitive value, transfer cost, customer satisfaction and customer trust are positively correlated with customer loyalty, where customer satisfaction and customer trust have a greater impact on loyalty compared with the other two independent variable factors. The VIF (variance expansion factor) is all less than 10, indicating that there is no multiple collinearity among the various independent variable factors.

\subsubsection{Statistical analysis of each factor description}

(1) Customer cognitive value 
International Journal of Business Management and Economic Review

Vol. 5, No. 01; 2022

ISSN: 2581-4664

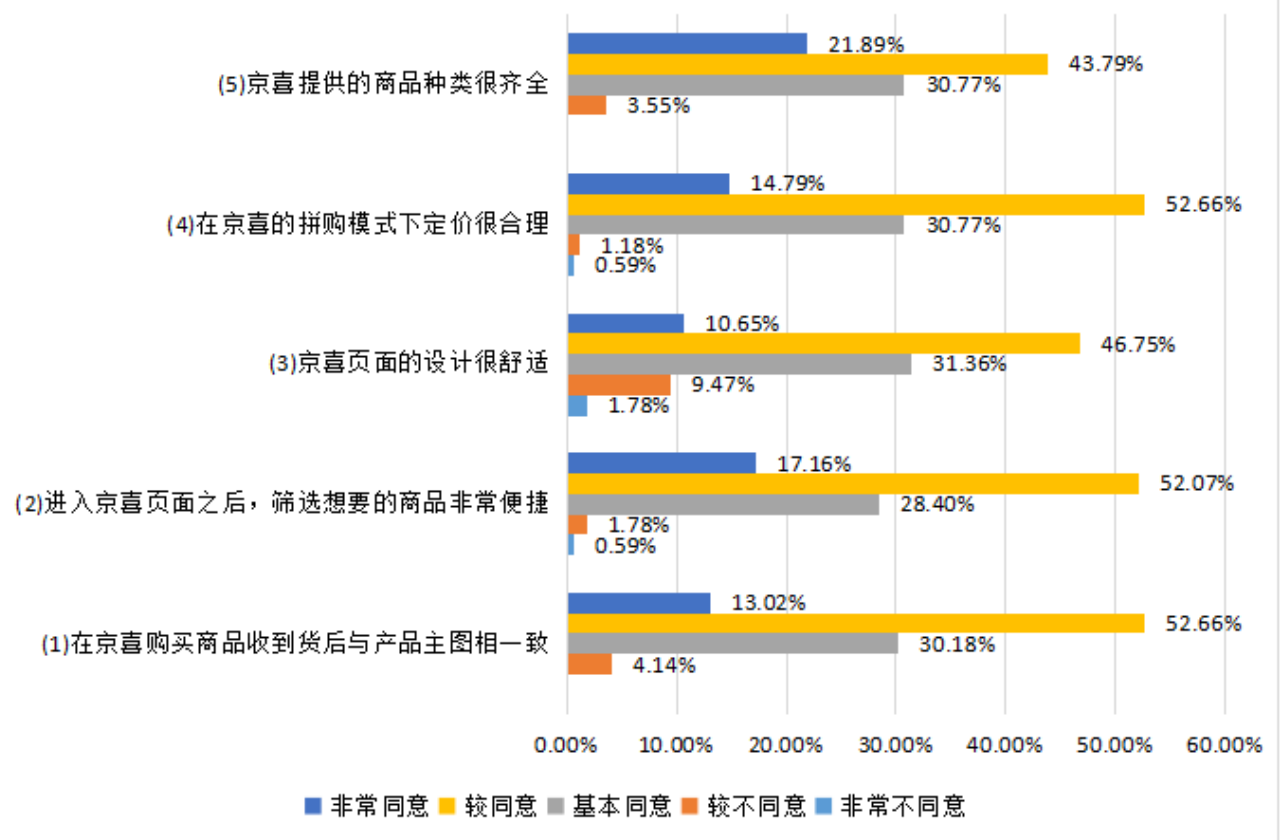

Figure 3-1 Statistics of "Customer Cognitive Value" of Jingxi Customers

As can be seen from Figure 3-1, in terms of measuring customer cognitive value, the evaluation of each problem focuses on "very agree", "" agree "and" basic agree ", only a few people" not agree "and" very disagree ", indicating that customers have a high evaluation of cognitive value of Jingxi.

On T1: these two issues: "Buying goods in Jingxi is consistent with the product main picture" and T3: "the design of Jingxi page is very comfortable", the proportion of survey objects choosing "disagree" is larger compared with other problems, indicating that Jingxi's product display and processing and the design of shopping interface need to be improved.

(2) cost of transfer 
International Journal of Business Management and Economic Review

Vol. 5, No. 01; 2022

ISSN: 2581-4664

(10)如果使用其他网站购物, 会失去京喜提供的好 产品和服务

(9)相比其他网站, 在京喜上很容易就能搜索到其他 平台同样的产品

(8)相比其他网站, 熟瑟京喜的购物平台需要很小的 精力, 很客易接受

(7)相比其他网站, 对京喜推出的购物返红包活动力 度更满意

(6)相比其他网站, 在京喜上积累的邀新福利可以享 受更大的优惠力度
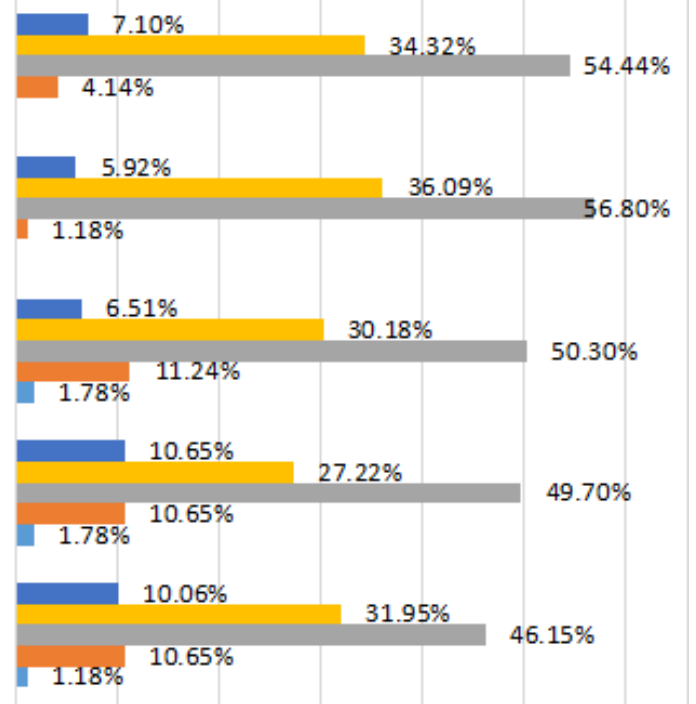

$0.00 \% \quad 10.00 \% \quad 20.00 \% \quad 30.00 \% \quad 40.00 \% \quad 50.00 \% \quad 60.00 \%$

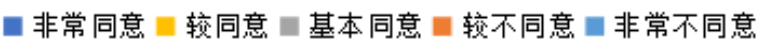

Figure 3-2 The "Transfer Cost" statistics of Jingxi customers

As can be seen from Figure 3-2, T6: "compared with other sites, accumulated new benefits can enjoy greater preferential strength" and T7: "compared with other sites launched to Beijing xi, the shopping back red envelope activities more satisfied" these two questions choose "very agree" accounted for the highest proportion, reached $10.06 \%$ and $10.65 \%$, indicating that compared with other transfer costs, customers care most about the shopping platform promotion activities;

For T8: "Compared with other websites, being familiar with Jingxi shopping platform needs a lot of energy, it is easy to accept," it can be seen that the survey object is quickly familiar with the acceptance of Jingxi shopping platform;

For T9: "compared to other sites, it is easy to search on other platforms the same products" and T10: "if you use other sites shopping, will lose good products and services" these two problems only fewer people chose "don't agree" compared to other transfer costs, customer psychological cost of jingxi platform is lower.

(3) Customer satisfaction 


\section{International Journal of Business Management and Economic Review}

Vol. 5, No. 01; 2022

ISSN: 2581-4664

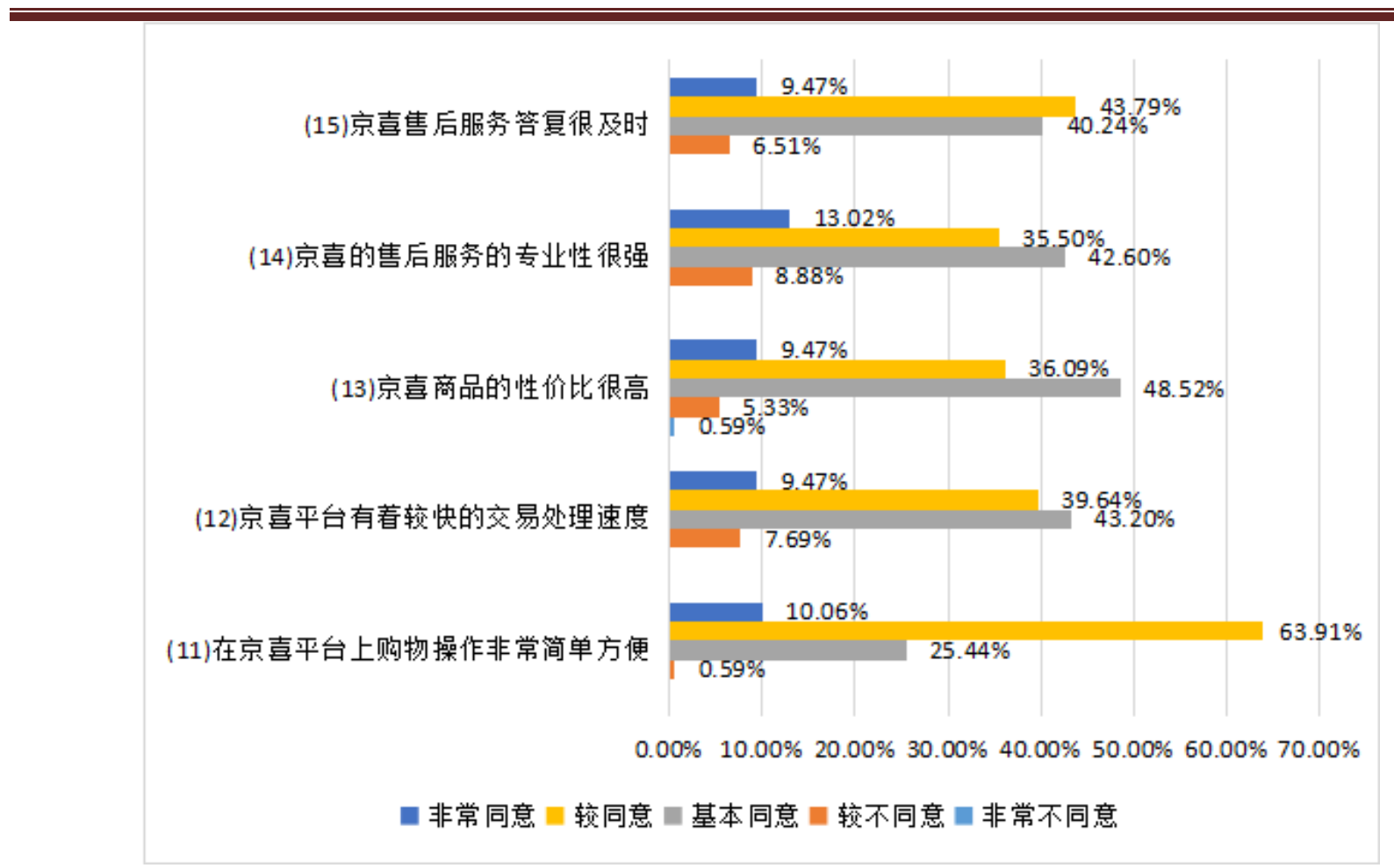

Figure 3-3 The "Customer Satisfaction" statistics of Jingxi

As can be seen from Figure 3-3, in the issue of customer satisfaction, the problem evaluation focuses on "more agree" and "basic consent", and only a few people "disagree" and "very disagree", indicating that customers have a high evaluation of comprehensive satisfaction with Jingxi.

For T11: "shopping operation is very simple and convenient on Jingxi platform", only $0.59 \%$ of people chose to "more do not agree", indicating that Jingxi shopping operation makes customers satisfied;

For T12: "Jingxi platform has a faster transaction processing speed" this problem, 7.69\% of the respondents chose to "more do not agree", which can show that although Jingxi's current transaction processing is faster, but it should continue to strengthen;

However, for T13: "the cost performance of Jingxi commodities is very high", $0.59 \%$ of people chose to "very disagree", although it is relatively low, but need to be paid attention to;

In view of the after-sales problem, T14: "Jingxi's after-sales service is very strong" and T15: "Jingxi after-sales service reply is very timely". The people who choose "who do not agree" accounted for $8.88 \%$ and $6.51 \%$, respectively, which shows that Jingxi's after-sales service needs to be strengthened.

(4) Customer trust 


\section{International Journal of Business Management and Economic Review}

Vol. 5, No. 01; 2022

ISSN: 2581-4664

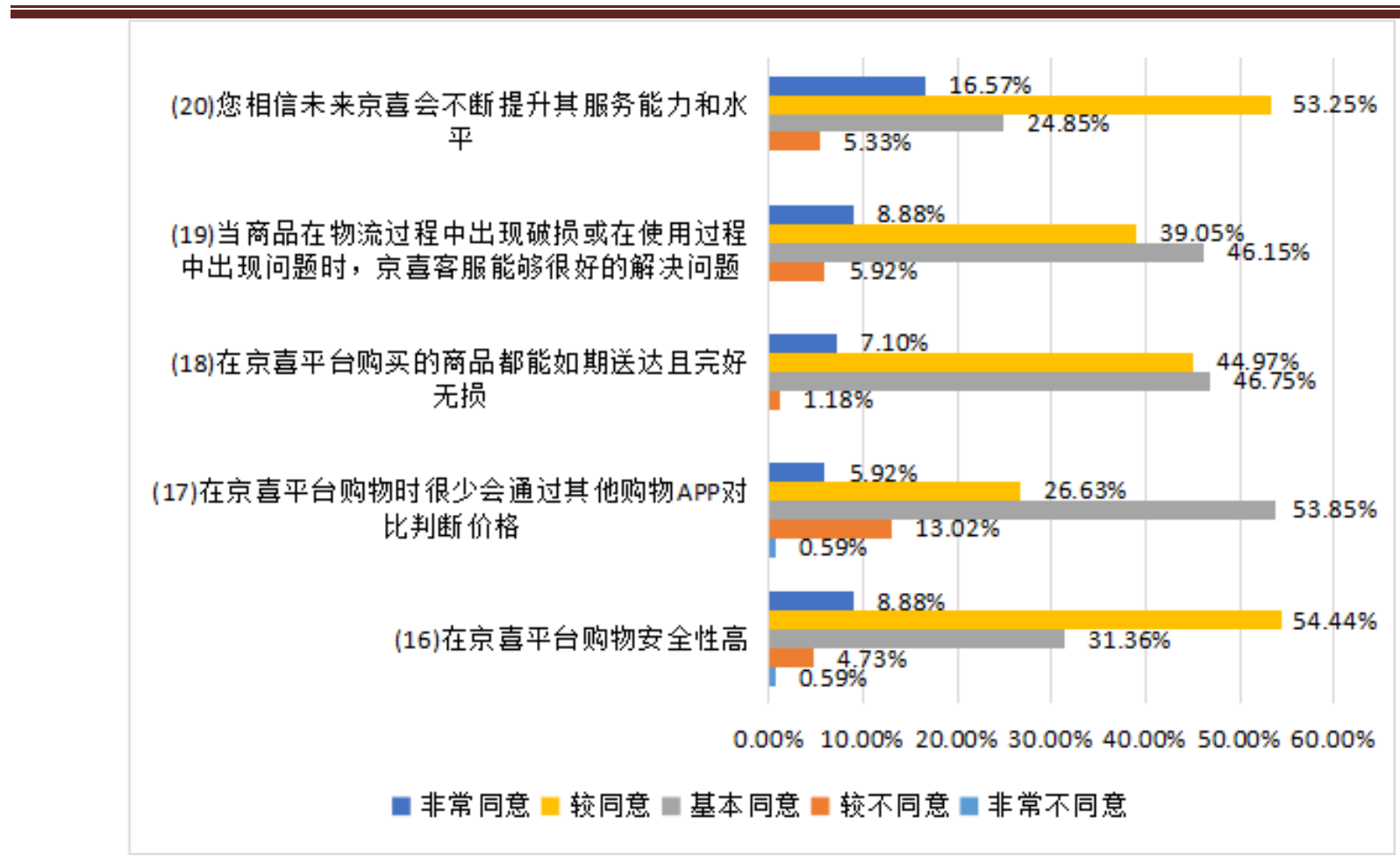

Figure 3-4 The "Customer Trust" statistics of Jingxi

As can be seen from Figure 3-4, in the issue of customer trust, customers evaluate highly of the comprehensive trust of Jingxi.

For T16: "high shopping security on Jingxi platform", 4.73\% of people chose to "disagree" and $0.59 \%$ chose to "disagree", indicating that the shopping security on Jingxi platform needs to be improved;

For T17: "I rarely judge the price through other shopping APP comparison when shopping on Jingxi platform", 13.02\% of the survey respondents chose "disagree", and $0.59 \%$ of the survey respondents chose "very disagree", indicating that the survey respondents were highly sensitive to the price;

But for T18: "in jingxi platform can be delivered on schedule and intact" and T19: "when the goods in logistics damage or problems in the process of use, jingxi customer service can solve the problem well" on these two problems, no one chose "very disagree", choose "disagree" accounted for $1.18 \%$ and $5.92 \%$ respectively, indicating that the survey trust in jingxi under these two problems.However, the number of choosing "disagree" also needs to be paid attention to;

In view of T20: "you believe that Jingxi will continuously improve its service ability and level in the future", the people who choose to "do not agree" accounted for $5.33 \%$ and $0.00 \%$, respectively, which shows that the survey objects have high trust in the future development of Jingxi.

(5) Customer loyalty 
International Journal of Business Management and Economic Review

Vol. 5, No. 01; 2022

ISSN: 2581-4664

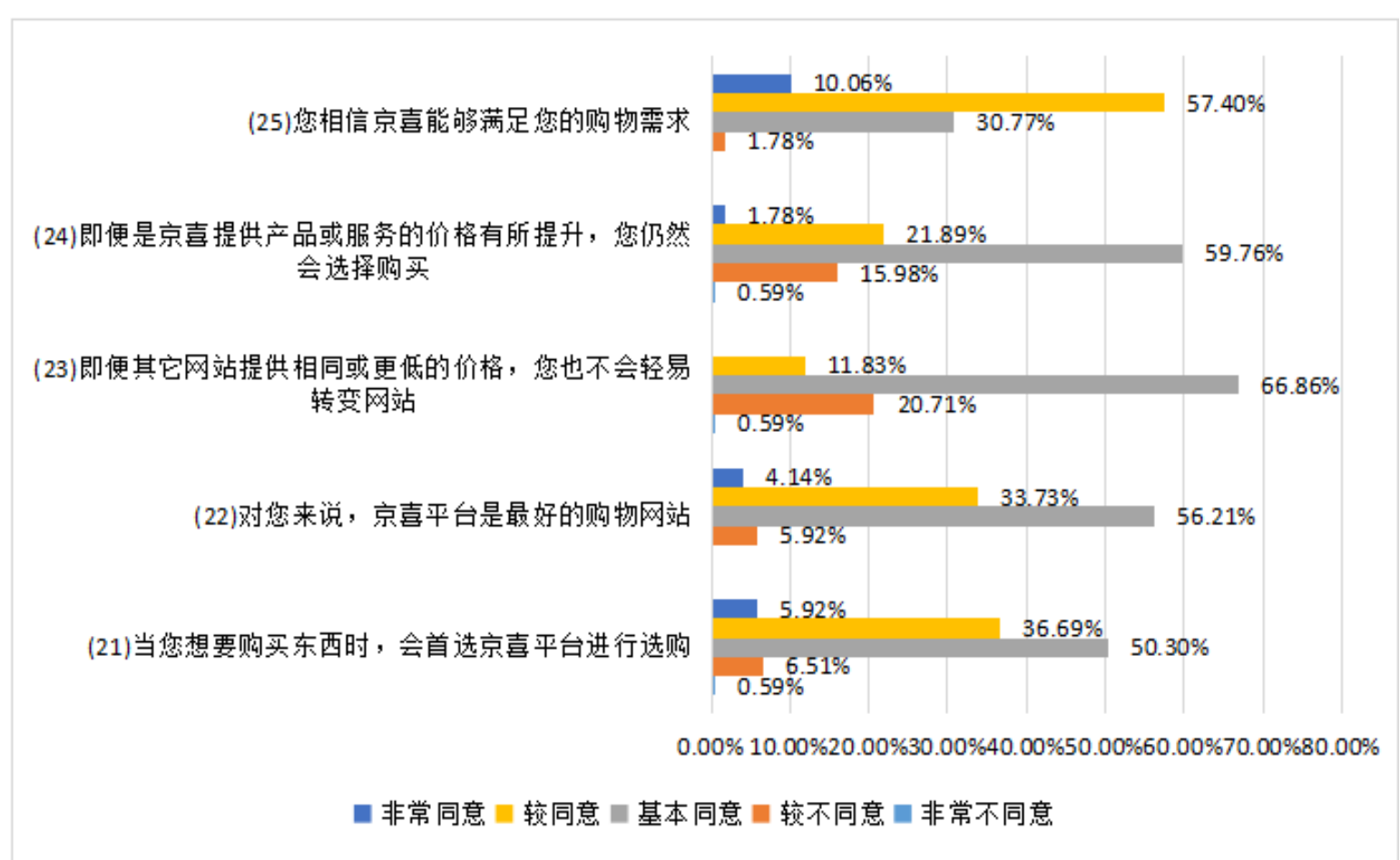

Figure 3-5 Customer loyalty of Jingxi

Loyalty is the core factor of this study. Five questions are set for customer loyalty in the questionnaire. From Figure 3-5, among the 5 questions measuring loyalty, T21: "When you want to buy something, you will choose" more consent "and" basic consent ", accounting for $36.69 \%$ and $50.30 \%$, indicating that the survey objects tend to be more willing to buy in Jingxi;

In terms of price, T23: "15.98\% will not easily change the website even if other websites provide the same or lower price" disagree, $0.59 \%$ choose "very disagree," and T24: "Even if Jingxi provides products or services, $20.71 \%$ choose to" disagree ", $0.59 \%$ " very disagree ", indicating that the survey object is more sensitive to the price of shopping websites, and the greater probability of lower loyalty generated by the price.

For T22: "Jingxi platform is the best shopping website for you" and T25: "You believe that Jingxi can meet your shopping needs", only 5.92\% and 1.78\%, which shows that the respondents have high trust in Jingxi, but still need to be improved.

\section{SUGGESTIONS ON IMPROVING CUSTOMER LOYALTY IN JINGXI}

According to the questionnaire data analysis of various factors, the improvement is proposed as follows:

\subsection{Improve customer cognitive value recommendations}

\subsubsection{Keep the physical product object consistent with the main drawing description}

For new products in the store, to reduce the color difference, fair and objective description of the product details, and for some error-prone products, such as screw diameter, the size of the mobile phone as a reference, can let the customer accurately understand the physical size of the product, to ensure that the customer receives the product meets the expectations.

\subsubsection{Personalized display of the Jingxi shopping interface}


International Journal of Business Management and Economic Review

Vol. 5, No. 01; 2022

ISSN: 2581-4664

For different users, you can display and recommend recently purchased or often searched commodity information to users in the world, stimulate users's interest in buying, to a certain extent can improve customer satisfaction in a good way, at the same time can save user search time, improve customer loyalty and improve the transaction volume of the platform.

\subsection{Improve transfer cost recommendations}

Increase promotions and improve user engagement.Platform can sign in to the customer every day and each consumption confirmation after the receipt according to the different consumption amount gives different number of points, points can reach a certain number of certain products or red envelope coupons, which can let customers produce the first in Beijing xi platform shopping potential consciousness, at the same time can increase the user activity of the platform.

\subsection{Improve customer satisfaction recommendations}

\subsubsection{Set the maximum shipping time limit}

Longer delivery time will affect to a certain extent the customer desire to buy the product, to ensure that customers can quickly receive products, can let the big store set the longest delivery time, if extended delivery will give customer without threshold coupon compensation, this can let customers customer have a certain understanding of their receiving time and accept, reduce customer complaints, stable customer group.

\subsubsection{Ensure the cost performance of the products}

Customers have a high sensitivity to the price. If the price of the product is higher than that on other platforms, it will lose certain customers and reduce the preferred choice of Jingxi in the hearts of customers.Jingxi platform must carefully check the quality of its products when reviewing the settled merchants.

Merchants can understand the quotation of relevant products on other platforms through the network and make the appropriate price; adopt the pre-sale mode to determine the purchase quantity according to the response degree of pre-sale. A large number of products can reduce the price of products to a certain extent.

The platform increases its activities in the original regular activities to attract major merchants and customers to participate. The promotion mode can increase the turnover of the platform while increasing the willingness of customers to purchase, which is conducive to increasing the competition of the platform.

\subsubsection{Improve after-sales service}

Consumers 'dissatisfaction with after-sales service will reduce users' satisfaction with the platform. Therefore, we should build a sound after-sales service system, timely respond to problems to by users respond, reasonably compensate users for losses, and ensure that after-sales personnel are online in real time, so as to improve users' satisfaction with after-sales service.

\subsection{Improve customer trust recommendations}

\subsubsection{Ensure customer personal privacy and financial information security}

The platform should ensure that customers 'personal information is not leaked, and customers' personal privacy and consumer financial information security should be kept confidential, so that the platform has security characteristics, which is conducive to customers' shopping and consumption on the platform, win customer trust, so as to enhance customer loyalty.

\subsubsection{Build a good reputation}

On the basis of the original cooperation between manufacturers, the platform can increase some industrial belts across the country, and directly provide the best products to consumers 
Vol. 5, No. 01; 2022

ISSN: 2581-4664

through the manufacturers at the lowest price, so as to attract consumers with unique resource advantages.

Optimize the web design of the platform, so that users can quickly find their own modules when browsing the web. At the same time, they can personalized recommend and display the recently purchased or browse goods to users, save customers' shopping time, and quickly find the goods they need.

\subsubsection{Commitment product quality and provide guarantee}

Product quality is one of the most important aspects when customers choose a product.In the process of trading, goods can go through multiple links to finally reach the user. Therefore, the quality of goods is affected by various factors. The platform should strictly control the product audit mechanism of the platform stores, ensure damage for fresh products, and ensure that the quality of products is guaranteed.

\section{PERORATION}

\section{1 research conclusion}

Cultivating customer loyalty plays a very important role in the continuous development of enterprises and improving their market share. With the continuous development of e-commerce, customer loyalty has become the main factor to maintain the growth of enterprises. This paper focuses on the current situation of customer loyalty of customer loyalty, and results that the customer cognitive value, transfer cost, customer satisfaction and customer loyalty, suggesting how to improve customer loyalty. In order to attract and retain loyal customers, Jingxi platform must maintain the product consistent with the main drawing description, increase promotion activities during customer use, and improve customer engagement.At the same time, in the purchase process of customers, we must ensure the customers' personal privacy and financial information security, provide the quality guarantee for the products on the shelves, and establish a perfect after-sales service.We look forward that Jingxi will obtain greater user traffic in its future development while enhancing its long-term loyal customers and enhancing its market competitiveness.

\subsection{Limitations and perspectives}

This study was based on the purpose of the model of the existing literature, and analyzed the factors of current customer loyalty through the results of the questionnaire.However, this study has certain limitations, specifically manifested in:

\subsubsection{The survey subjects were more concentrated}

Because the questionnaire is distributed online, the people who choose to answer to a certain extent may probably have greater loyalty to Jingxi itself, so it will increase the overall value of the research survey to a certain extent.In the future, questionnaires can be distributed in the form of combining online and offline, which can greatly ensure the accuracy of the data and enhance the reliability of the investigation.

\subsubsection{There are few research factors}

There are many factors affecting customer loyalty. This paper only selects customer loyalty, customer cognitive value, customer cost, customer satisfaction and customer trust, which may lead to biased research results.

\section{REFERENCE}

China Internet Network Information Center. The 47th Statistical Report on China Internet 


\section{International Journal of Business Management and Economic Review}

Vol. 5, No. 01; 2022

ISSN: 2581-4664

Development [R]. 2021.

foresight Industry Research Institute. Analysis of the Market Development Status of China's Ecommerce Industry in 2020 [R]. 2020.

foresight Industry Research Institute. China e-commerce market competition and enterprise competition strategy Analysis Report [R]. 2020.

Mob research institute. The 2020 sinking market map [R]. 2020.

iResearch Consulting Research Institute. China Social e-commerce Industry Research Report [R].

2019. QuestMobile. Sinking Market Report [R]. 2019.

The Digital 100 Data Research Institute, the Social E-commerce Working Group of the Internet Association of China, and the Chuangqi Social E-commerce Research Center. 2020 China Social e-commerce Consumer Shopping Behavior Research Report [R]. 2020.

$\mathrm{Yu} \mathrm{Li}, \mathrm{Wu}$ Lihua. Customer Relations Management [M]. Beijing: Renmin University of China Press, $61.2009 \sim 71$.

Han Xiao. Study on Customer Loyalty Strategies in the Network Environment [J]. Modern Marketing (Next ten magazine), 2019, (10): 82 83.

Li Yuhui, Fu Taiping. Avenues to improve customer loyalty [J]. Economic Management, 2003, (21): 75 78.

Liu Yang. Research on Customer Loyalty and Its Improvement Methods [J]. Enterprise Reform and Management, 2017, (22): 4 5.

Chen Mingliang. An Empirical Study of Customer Loyalty Determinants [J]. Management Science, 2003, (05): 72 78.

Deng Aimin, Tao Bao, Ma Yingying. Empirical study on customer loyalty [J]. China Management Science, 2014, (06): 94 102. 